\title{
Diglossic Principles in Shona Lexicography
}

Esau Mangoya, African Languages Research Institute (ALRI), University of Zimbabwe, Harare, Zimbabwe (emangoya@arts.uz.ac.zw)

\begin{abstract}
This article looks at diglossia in Shona dictionaries. Diglossia is seen here as the differential and preferential use of a language or a dialect in dictionaries. The main language spoken in Zimbabwe is Shona. Over a period of about one and a half century, at least twenty Shona lexicographic publications including glossed word lists and medium-sized dictionaries have appeared, examples of which are used in this article to demonstrate the diglossic principles in Shona lexicography. As is the case with many languages, Shona is also in contact with other languages, among them English, which during the colonial era was declared the official language of the country. As a result the dictionaries that were compiled were bilingual. In these dictionaries, involving English and Shona, the bias was towards satisfying the needs of English-speaking users, as much of the detail, including the headword entries, was in English. However, with the need to empower the indigenous languages of the country, there was a deliberate move to promote Shona. This saw a change from the compilation of bilingual dictionaries to monolingual dictionaries which resulted in a different mode of diglossia as the dialects within Shona itself do not enjoy equal status in the dictionaries, because some dialects are given preference above others. This article traces the diglossic tendencies among languages and within the same language in dictionaries involving Shona.
\end{abstract}

Keywords: DIGLOSSIA, LEXICOGRAPHY, SHONA, SOCIOLINGUISTICS, HIGH VARI-
ETY, LOW VARIETY, SYNONYM, PHONOLOGY, ENTRY, TONE, DEFINITION

Opsomming: Diglossiese beginsels in Sjonaleksikografie. Hierdie artikel beskou diglossie in Sjonawoordeboeke. Diglossie word hier gesien as die diskriminerende en begunstigende gebruik van ' $n$ taal of 'n dialek in woordeboeke. Die hooftaal wat in Zimbabwe gepraat word, is Sjona. Oor 'n tydperk van ongeveer een en 'n half eeu, het ten minste twintig Sjona- leksikografiese publikasies verskyn, insluitende geglosseerde woordelyste en middelgroot woordeboeke, voorbeelde waarvan in hierdie artikel gebruik word om die diglossiese beginsels in Sjonaleksikografie te toon. Soos die geval is met baie tale, is Sjona ook in kontak met ander tale, onder hulle Engels wat gedurende die koloniale tydperk as die amptelike taal van die land verklaar is. Gevolglik was die woordeboeke wat saamgestel is, tweetalig. In hierdie woordeboeke waarby Engels en Sjona betrokke was, was die neiging om die behoeftes van Engelssprekende gebruikers te bevredig omdat baie van die besonderhede, insluitende die trefwoordinskrywings, in Engels was. Met die behoefte egter om die inheemse tale van die land te bemagtig, was daar 'n doelbewuste beweging om Sjona te bevorder. Dit het 'n verandering gebring weg van die samestelling van tweetalige woordeboeke na eentalige woordeboeke, wat gelei het tot ' $n$ ander vorm van diglossie omdat die dialekte binne Sjona self nie gelyke status in die woordeboeke geniet nie, maar aan sommige voorkeur bo ander gegee word. Hierdie artikel spoor die diglossiese neigings na tussen tale en binne dieselfde taal in woordeboeke waarby Sjona betrokke is. 
Sleutelwoorde: DIGLOSSIE, LEKSIKOGRAFIE, SJONA, SOSIOLINGUISTIEK, HOË VARIËTEIT, LAE VARIËTEIT, SINONIEM, FONOLOGIE, INSKRYWING, TOON, DEFINISIE

\section{Introduction}

This article seeks to explore how the principles of diglossia have had a bearing on the production of lexicographic works in Zimbabwe. The linguistic variation to be considered will be both within the same language and between two distinct languages.

The term diglossia, coined by Ferguson (1959), has been used primarily in sociolinguistic studies. It refers to the differential use of two language varieties in a given language community and in a given geographical region. In principle, Ferguson has a situation in mind where two or more varieties of the same language are used by some speakers in a speech community under different conditions. This entails some level of switching between the varieties in relevant situations. The concept assumes that there is use of one language variety in one set of circumstances and another under different conditions. The varieties are classified as either being High $(\mathrm{H})$ or Low $(\mathrm{L})$. The $\mathrm{H}$ variety is considered superior and the L variety inferior.

Whilst Ferguson's notion of diglossia concerns varieties of the same language, observations in other language situations have led to modifications to Ferguson's mode of diglossia. Fishman's modification broadened the concept of diglossia to embody the assignment of different and separate languages existing in a speech community to serve different tasks in society (Fasold 1984: 40). Thus Fishman includes what he calls a separate code with reference to separate languages. With Fishman's modification, separate languages are assigned different roles whereby some have $\mathrm{H}$ status while others are relegated to $\mathrm{L}$ status. Both Ferguson's and Fishman's emphasis is on the distinctive function of the varieties within the same society. What Fishman did was to broaden the concept but firstly fully accommodating Ferguson's mode which only focuses on the use of varieties of the same language to its application to the use of separate languages. There are no contradictions between the two scholars and as a result Fishman also adopted Ferguson's rubrics of diglossia which distinguish the $\mathrm{H}$ variety which must:

(a) have a special function assigned to it,

(b) be a prestigious variety,

(c) have a long history of literary heritage,

(d) be acquired through formal education,

(e) enjoys a stable relationship with its $L$ varieties, and

(f) be standardised by way of formal codification.

Dictionaries are understood to represent words and also to be repositories of the words in a language. Lexicographic works reflect the social environment in which they are created, this environment again shaping these works. Lexico- 
graphy has to follow particular systematising principles to achieve qualities such as user-friendliness, marketability, relevance for and acceptability by the users. If the dictionary is seen as a repository of the words in a language, then it captures the living language, including the social stratification of the language and its varieties.

\section{The Colonial History: Headword Inclusion}

In Zimbabwe, English became imposed as the official language during the colonial era. As a result of this, it automatically assumed the $\mathrm{H}$ status. This led to the local languages being subjugated to the L status as English became the lingua franca in all official spheres and also in the education system. English had already been fully documented by way of dictionaries and grammar books. As far as lexicography was concerned, English was well developed with numerous publications ranging from large advanced dictionaries to small pocket dictionaries. The fact that all these were compiled abroad where English originated gave them unquestionable authority, hence there has been no reviews of these dictionaries by Africans. They already met the standards in terms of Ferguson's rubrics, coming as a complete package. So English became the $\mathrm{H}$ with its special function juxtaposed against the undeveloped local indigenous Ls.

However, in time, the need arose to develop the indigenous languages for enhanced communication. This was not for the purpose of empowering the languages but for the purpose of understanding the African idiom as reflected by the initial attempts by white missionaries. They were concerned with the spread of the gospel to the locals, embarking on standardising the indigenous languages. But the language situation remained with English set as the official language. Whatever followed revolved around the established English language. This was also reflected in the lexicography where the Shona headword entries would be explained in English. Again the H English would assist in standardising the undeveloped Shona. Many reasons have been put forward why English would always filter into and play a major role in dictionaries meant not only to standardise Shona but also to assist English speakers to learn Shona. This article does not dispute this fact but whatever the reasons, the resultant situation is diglossic in nature. Indigenous Shona had to be juxtaposed against the standard English.

This can be demonstrated from Barnes's 1932 dictionary using as example the word -nyima (to be stingy).

-nyima, $v b$. tr.; to treat meanly, be mean or stingy to; to stint; -zinyima, to deny oneself; -zinyima-zokudya, to fast; wandinyima zokudya, you have stinted me of food, you haven't given me enough food (i.e., what is due).

Similarly, in Hannan's Standard Shona Dictionary of 1959 (second edition 1974), 
the headword entries are Shona, but the explanations are in English. The impression is created that the standard should have been referred to English which dominates in the whole dictionary rather than Shona which only provides the headwords. The English $\mathrm{H}$ is being accorded the higher status and Shona is being standardised via English as demonstrated in the example of the entry ngwachata (idiophone of a rattling noise).

ngwachata (LLL) KMZ ideo of Falling (object that rattles; e g bundle of dry reeds). 2. Z of Falling through weakness. [...]

The Shona entry ngwachata is followed by an indication of the tones of the three syllables of the word, ngwa- + -cha- + -ta which are all low as shown by the three Ls (take note of the differences between the use of $\mathrm{L}$ in tone and diglossia in this article). The tone indication is followed by the bold letters KMZ indicating that the word is used in the Karanga, Manyika and Zezuru dialects. The approach then was to indicate in which Shona dialects the word is used. The absence of the bold Ko and $\mathbf{N}$ means the word is not common in the Korekore and Ndau dialects. After the indication of the dialect comes the English definition. In the same entry, appears another meaning given as definition 2. This second meaning of the word is found only in Zezuru as indicated by the bold Z. The definition is also given in English.

The dominating language is English. The medium of communication is predominantly English. The information given by the dictionary is for people who understand English. This observation is reinforced by the fact that this dictionary has an English-Shona index at the end where the headword entries are English and again only Shona equivalents are given while the rest of the definitions are in English, as shown in the following example from the index.

cough n: chikosoro $7 \mathrm{KKoMZ}$. C that causes breathlessness: rutaitai $11 \mathrm{Z}$. Whooping c: chipembwe $7 \mathrm{KM}$; chipwembwe $7 \mathrm{M}$.

Despite the dictionary being labelled Standard Shona Dictionary the role Shona plays in the dictionary is minimal. It is clear that the target user should be someone who already speaks English.

Subsequent bilingual dictionaries tried to minimise the dominance of English, e.g. A Basic English-Shona Dictionary (1975) and Duramazwi (1981) both compiled by Dale. The first has English headwords while the second has Shona headwords. Just as in the Standard Shona Dictionary, English plays a dominant role in A Basic English-Shona Dictionary. Headwords and explanations are presented in English with the Shona equivalents given at the end. The following is an example of how the headword African is treated in the dictionary.

African belonging to Africa or the people of Africa adj., e.g. tsika dzevatema (African customs)

Fishman as quoted by Fasold (1984: 54) says: "Whilst diglossia can remain for 
years non the less diglossic relationships do change and show characteristic signs of change." This type of change is reflected in Dale's second publication Duramazwi where Shona is now given a prominent role. Thus this dictionary has Shona headwords, but the bulk of the information comprising the definitions is in Shona. English equivalents are given last. It has been argued that Duramazwi paved the way for the publication of Shona monolingual dictionaries as Shona's ability to describe itself is demonstrated. This can be seen from the following example from Dale's Duramazwi.

garo 5, mag-6 (LL) Izwi rinoreva kuti nzvimbo inogara pasi kana chinhu chagadzikwa. $\mathrm{n}$ base of a thing; buttock, bottom (polite term)

This treatment shows why the Shona $\mathrm{L}$ is deemed to be moving up towards the $\mathrm{H}$ status. In earlier dictionaries, the English $\mathrm{H}$ dominates. However, with English speakers gaining more knowledge of Shona, they started focusing to a greater extent on the empowerment of the Shona L. Whilst a positive development is noted with the production of Duramazwi, Shona is not totally granted freedom from the English H's dominance. In a way, English still has the authority as it follows on the definition despite the use of Shona in the definitions. As long as the dictionaries compiled are bilingual, the H status of English continues to dominate over the Shona L status.

This situation has resulted in a move towards Shona monolingual dictionaries in an attempt to accord Shona the $\mathrm{H}$ status, which it cannot enjoy in a field where it has to compete with English. This has however led to the development of new forms of diglossia. As has been pointed out above, diglossic models can also be transformed or modified. New trends have developed where the diglossic situation has now moved to the internal functions of Shona. Once the focus is on Shona the diglossic function of the dialects of Shona has to be considered. As was the case with the languages, the dialects are similarly in competition for diglossic status.

\section{Competing Dialects}

Away from the level at which English and Shona are competing for authority, another form of diglossia makes its appearance at the level of the dialects. This is more apparent in the Shona monolingual dictionaries where the Zezuru, Karanga, Manyika, Ndau and Korekore varieties are also found not to enjoy equal status. As reflected in the treatment of definitions, and synonyms and variants, Zezuru has been shown to enjoy the $\mathrm{H}$ status in comparison with the other dialects.

\section{Dialect $\mathrm{H}$ and L Stratification in the Dictionaries}

With regard to the dialects, the compilers of the Shona monolingual dictionary 
had to have a standard for treating the definitions. Duramazwi reChiShona (1996), the first ever Shona monolingual dictionary, was followed by the publication of Duramazwi Guru reChiShona (2001). When the different definitions in the two dictionaries are considered, it is notable that the rest of the dialects take a second place to Zezuru. At the same time, it becomes clear that the Shona dialects share a lot of vocabulary. Going through the dictionaries reveals that there was a deliberate preference for Zezuru words where alternatives from the other dialects could have been used as well. Examples of such words are -rumba (run) from Ndau, and -motsa (grind finely) from Karanga. These words were avoided in the definition fields. The example below shows how the verb -rumba was treated in Duramazwi Guru reChiShona.

-rumba D itik. Kumhanya.

The abbreviation D stands for "low tone". The indication itik means the verb is intransitive. The meaning given is simply "To run", but the verb root for "run" used with the infinitive $k u$ - from the Zezuru dialect is -mhanya. So, for the actual meaning of the Ndau verb -rumba, the user has to go to the Zezuru term -mhanya. The Zezuru entry is given as follows:

-mhanya [-manya] K itik. ... Kana uchimhanya unenge uchikanda tsoka nekukurumidza, uchitomuka zvinokuita kuti ukasike kusvike kwauri kuenda. FAN -rumba, -tizira, -vanga,-dorinya,-wara, -gijima.

The variant of the entry follows in square brackets. "K" stands for high tone. After the tone comes "itik" which indicates that it is an intransitive verb. Then follows the actual definition, "When you run you will move your feet forward and bounce which makes you to come quickly to where you are going." After the definition follows "FAN" which is a shortening for the verb -fanana (is synonymous). Then, in italics, is given the range of synonyms which do not carry definitions separately, starting with the Ndau -rumba. The definition of the Ndau term is arrived at via the Zezuru entry.

The occurrence in the dictionaries of these entries peculiar to other dialects is a kind of concession. Their existence is recognised by having them as headword entries cross-referenced to their Zezuru equivalents. Their inclusion and cross-referencing to Zezuru mostly result from complaints raised by speakers of the other dialects. These followed the outreach programmes meant to ascertain the response of the target users to the pioneer monolingual dictionaries in their draft copy stages of production. There was an outcry from the Ndau and Korekore dialect speakers because many of their lexical items were omitted from these dictionaries which purported to be "purely" Shona. As a result, the second monolingual publication Duramazwi Guru reChishona was sensitive to these complaints so that many headwords from the other dialects were included. This at least was possible because, as an advanced dictionary, it was able to accommodate many headword entries. 
The first monolingual dictionary Duramazwi reChiShona had many of these dialect varieties omitted. Whilst it can be argued that the dictionary was a medium-sized dictionary, which could not contain so many entries, the guidelines showed diglossic tendencies as can be seen from the included headwords which mainly belong to the Zezuru dialect.

However, when headwords from the L status dialects were finally included in the much larger and more accommodative Duramazwi Guru reChiShona, they themselves still did not receive authoritative status. Whenever they were entered, as demonstrated above, they were referred to Zezuru H. As mentioned above, the Ndau -rumba is cross-referenced to -mhanya. Nowhere in the dictionaries is it given the authority and autonomy to be defined and described by Ndau vocabulary. Zezuru plays the $\mathrm{H}$ role. To this, Chimhundu (1979: 75) says: "One may claim that Zezuru is becoming the de facto prestigeladen standard language, not vis-à-vis the other dialects as such but their subdialects or local varieties."

This $\mathrm{H}$ status of the Zezuru dialect is also reflected in the treatment of the synonyms from the other Shona dialects. Although dialects share much vocabulary, they always have vocabulary peculiar to them which, in addition to unique phonological articulation, also helps to identify them. These peculiar dialect lexical items were entered in the monolingual dictionaries but were cross-referenced to the Zezuru forms, not being given the opportunity to carry the definitions themselves. Some such cross-referenced lexical items are given below.

\author{
Karanga \\ -svoda /soda/ \\ -shara / Jara/ \\ -nyara / nara/ \\ -bwereketa /byereketa/ \\ shangadzi / Jangadzi/ \\ zvirokwazvo / zirokwazo/
}

\section{Korekore}

murendo /murendo/ manhoko /manoko/ mbani /mbani/

\section{Ndau}

upfu /upfu/

bonore /bonore/

nyamashi /namaji/

-petuka / petuka/

-dhana /dana/

\section{Zezuru}

-nyara /nara/ (be shy)

-sarudza / sarudza/ (choose)

-neta / neta/ (be tired)

-taura /taura/ (speak)

shanje / Janje/ (type of grass)

chokwadi / $\mathrm{t}$ Jokwadi/ (truth)

muenzi /muenzi/ (visitor) manheru / maneru/ (evening) ndiani /ndiani/ (who is it)

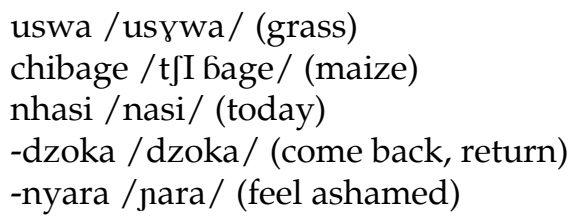




\section{Manyika}

gwanzi /gwanzi/

ehunde /ehunde/

nzira /nzira/(road, path, way)

dima / dima/

ehe /ehe/ (yes)

mbambaira / mbambaira/ (sweet potato)

These lexical items from the other dialects are not defined using the dialects' vocabulary. They are cross-referenced to the Zezuru H lexical items which are given the authority to carry the definitions. However, there are cases where the H's authority is reduced or neutralised. These are cases where some of the lexical items are peculiar to certain dialects not having a complete equivalent meaning in the Zezuru H. Examples of this are some headword entries from Ndau shown below.

\section{Ndau \\ yaya /jaja/ (elder sister) \\ taita / taita/ (elder sister)}

In the other dialects, there are terms referring to "sister" in general without the specification of being younger or older. The lexical item that denotes "sister" in general is an adopted term sisi from English "sister". However, it has had its meaning slightly shifted from that of English. As an adoptive it refers to "elder sister", and the reference could be used by both younger brother or younger sister, whereas yaya and taita specifically denote an elder sister, as used by a younger sister. It is only under these special circumstances that the L lexical items are given the opportunity to carry their own definitions without having to be referred to the $\mathrm{H}$ variety. However, although they escape the diglossic stratification in not being cross-referenced to the Zezuru entries for meaning, they are nevertheless defined using Zezuru vocabulary, Zezuru therefore once more dominating as the $\mathrm{H}$.

The dominance of the Zezuru $\mathrm{H}$ also manifests itself in the treatment of variants which are quite common, particularly between the Zezuru and Karanga dialects. It has been noted that Karanga prefers fricatives whereas Zezuru uses nasal + fricative or stop + fricative combinations as shown in the examples below.

Examples where Zezuru has nasal + fricative combinations:

Karanga
zhira / zira/
zhara / zara/
zheve / zeve/
zhou / zou/

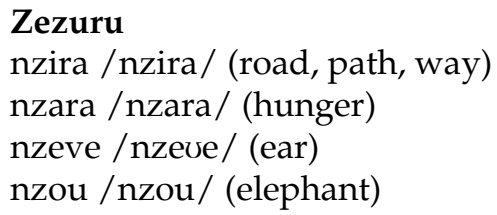

Examples where Zezuru has stop + fricative combinations:

Karanga svazva /saza/

\section{Zezuru}

tsvanzva / tsanza/ (type of wild fruit) 


$$
\begin{aligned}
& \text {-svedza /sedza/ } \\
& \text { shanga / Janga/ } \\
& \text { shezha / Jeza/ }
\end{aligned}
$$

\author{
tsvedza /tsedza/ (sip off) \\ tsanga /tsanga / (grain of seed) \\ tsenza /tsenza/ (yam)
}

Lexical items from Zezuru and their variant counterparts from Karanga are given as headword entries in Shona dictionaries. The lexical items from Zezuru have $\mathrm{H}$ status as they have authority over their Karanga counterparts. Zezuru has the sole mandate to carry the definitions and any other information elaborating the meaning of the entries. Definitions and elaborative information have to be carried by the term belonging to the $\mathrm{H}$ variety, all the lexical items from the $\mathrm{L}$ varieties therefore being cross-referenced to the Zezuru $\mathrm{H}$ variety.

In certain cases in situations where there is shared vocabulary amongst all the Shona dialects, some dialects are subjugated to this $L$ status regarding variants because of being exclusive of the general trend among the dialects. In such circumstances, the particular dialect remains the only one with $L$ status as has been noted with Manyika's and Korekore's preference for the /w/ phonetic element as in -waka (build) where all the other dialects would use /v/, thus having -vaka. In such cases, Manyika and Korekore remain exclusive, while the other dialects all acquire $\mathrm{H}$ status. If numbers are taken into account, Korekore and Manyika remain in the minority. Those elements peculiar to them are disregarded without any proper justification. There is a deliberate move towards this non-recognition of the $/ \mathrm{w} /$ phoneme in those dialects, since all the words from the dialects that involve / $/$ w would then be variants of the Manyika and Korekore forms. This results in a diglossic situation where Manyika and Korekore words with $/ \mathrm{w} /$ onsets remain unrecognised in dictionaries. The existence of the lexical items with / w/ phoneme onsets is disregarded for inclusion in dictionaries, but is only realised in the speech of speakers of the dialects. As Trudgill (1983: 114) puts it: "The low variety ... is used in conversation with family and friends, radio serials, political and academic discussions, political cartoons, and 'folk' literature."

Doke's 1931 standardisation recommendations led to this development of the L status of some of the dialects in which certain phonemes were not recognised in the Shona spelling system. He deliberately recommended that some Ndau and Korekore lexical items should be omitted. Examples of these peculiar to Ndau are words having the combination bilabial $/ \mathrm{m} /$ and voiceless stop $/ \mathrm{p} /$ such as mpatso (home). These are normally omitted from dictionaries together with words like muntu /muntu/ (person) which have the unrecommended combination of $/ \mathrm{n} /$ and $/ \mathrm{t} /$. As pointed out above, these are used mainly in speech and are not recognised in written form, which is always the case with $L$ varieties.

A similar case is the nouns of class 11 in Korekore. Korekore has a different realisation of the class 11 prefix $x u$ - as in xukomana (small boys) and xumbwa (small dogs). In the rest of the Shona dialects, these two are realised as tukomana and tumbwa respectively. The use of $/ \mathrm{x} /$ as a prominent feature only in 
the Korekore dialect has not been recognised in Shona dictionaries. Despite this exclusion of the Korekore lexical items, some of the dialects managed to challenge the Zezuru $\mathrm{H}$ and imposed their own peculiar character. An example is Karanga where the svi- prefix as in svimbudzi (thin goat) and svisikana (thin small girl) is a peculiarity. However, the Karanga dialect receives this kind of temporary $\mathrm{H}$ status from Doke's recommendations of standardisation where a certain preference for the Karanga dialect was given.

\section{Leakage from $\mathrm{H}$ into $\mathrm{L}$ in Adoptives}

There is a certain realisation of the $\mathrm{H}$ role English has always played and continues to play worldwide. English is considered a language of wider communication. Most technological terms are introduced through English. In the first place, as has been demonstrated above, the purpose of creating the bilingual dictionaries was to raise Shona from its L status. The general lexicographic idea was to bring it on par with English so that it could be used in all spheres of life where at the moment it has limitations. As a result, there has been a deliberate move to introduce as many as possible adopted new technological terms, a move which can be viewed as assisted leakage. Duramazwi Guru reChiShona (2001) and the biomedical dictionary Duramazwi reUrapi neUtano (2004) made it a deliberate policy to have the technological terms adopted from the English $\mathrm{H}$ included, resulting in the listing of terms such as:

kombiyuta (computer)

temberecha, temburicha (temperature)

abhakasi (abacus)

This was done to raise the functional capability of the Shona $\mathrm{L}$ as close as possible to the English H. In certain instances, these leakages are viewed with some resistance as the speakers feel that the indigenous L should have some linguistic regeneration. Through some form of affirmative action, they disregard the adoptive leakages and coin their own words to create a feeling that the $\mathrm{L}$ is gaining $\mathrm{H}$ status: "These are generally used only by those with some special interest in the language who therefore consciously avoid using foreign words when they can help it" (Chimhundu 1979: 78).

Such situations lead to a grey diglossic stratification where the $\mathrm{H}$ status of English is partly ignored and Shona coinages are given prominence. However, experience has shown that users, except in formal written language, avoid these coinages in general conversation. Examples of such coinages are:

\author{
Coinage \\ bhizautare \\ hambautare \\ dutavanhu \\ mugaradzakasungwa
}

\author{
Literal translation \\ metal horse (bicycle) \\ metal transporter (motorcar) \\ human transporter (bus) \\ ever ready person (policeman)
}


Some of these actually have a somewhat exaggerated denotation. Despite the knowledge that they are not so commonly used, lexicographers always include them in dictionaries to reflect the reality of the historical development of Shona. They were coined in reaction to the diglossic positioning of Shona to English.

\section{Conclusion}

Diglossia has been shown to be some form of natural power stratification among languages or dialects used by the same community. There are many factors causing it, including the historical development of the languages and their dialect varieties. The diglossic positioning of the dialects is not so much of a conflict as there is some form of standardised stratification. This diglossic situation develops over a long period of time so that other language-related or -based forms also follow the already existing stratification, as has been shown to be the case with Shona lexicography.

\section{Bibliography}

Barnes, B.H. 1932. A Vocabulary of the Dialects of Mashonaland in the New Orthography. London: The Sheldon Press.

Chimhundu, H. 1979. Some Problems Relating to the Incorporation of Loanwords in the Lexicon. Zambezia 7(1): 75-91.

Chimhundu, H. (Ed.). 1996. Duramazwi reChiShona. Harare: College Press.

Chimhundu, H. (Ed.). 2001. Duramazwi Guru reChiShona. Harare: College Press.

Dale, D. 1975. A Basic English-Shona Dictionary. Gwelo: Mambo Press.

Dale, D. 1981. Duramazwi: A Basic Shona-English Dictionary. Gweru: Mambo Press.

Doke, C.M. 1931. Report on the Unification of Shona Dialects Carried Out under the Auspices of the Government of Southern Rhodesia and the Carnegie Corporation. Hertford: Stephen Austin.

Fasold, R. 1984. The Sociolinguistics of Society. Oxford: Blackwell.

Ferguson, C.A. 1959. Diglossia. Hymes, D. (Ed.). 1964. Language in Culture and Society: 429-439. New York: Harper and Row.

Fishman, J.A. 1971. Societal Bilingualism: Stable and Transitional. Fishman, J.A. 1971. Sociolinguistics: A Brief Introduction: 73-90. Rowley, MA: Newbury House Publishers.

Hannan, M. 1959. Standard Shona Dictionary. Salisbury: The College Press.

Hannan, M. 1974. Standard Shona Dictionary. Second edition. Salisbury: Rhodesia Literature Bureau.

Mpofu, N. et al. (Eds.). 2004. Duramazwi reUrapi neUtano. Gweru: Mambo Press.

Trudgill, P. 1983. Sociolinguistics: An Introduction to Language and Society. Revised Edition. London: Penguin. 